EMS Annual Meeting Abstracts

Vol. 18, EMS2021-419, 2021, updated on 27 Aug 2021

https://doi.org/10.5194/ems2021-419

EMS Annual Meeting 2021

(C) Author(s) 2021. This work is distributed under

the Creative Commons Attribution 4.0 License.

\title{
Impact of dust storms and urban air pollution on PV-power systems: Case studies from Ghana
}

Stefanie Meilinger, Anna Herman-Czezuch, Armelle Zemo, and Matthias Bebber

Bonn-Rhein-Sieg University of Applied Sciences, International Center for Sustainable Development, Electircal Engineering, Mechanical Engineering, Technical Journalism, Sankt Augustin, Germany (stefanie.meilinger@h-brs.de)

In contrast to the German power supply, the energy supply in many West African countries is very unstable. Frequent power outages are not uncommon. Especially for critical infrastructures, such as hospitals, a stable power supply is vital. To compensate for the power outages, diesel generators are often used. In the future, these systems will increasingly be supplemented by PV systems and storage, so that the generator will have to be used less or not at all when needed. For the design and operation of such systems, it is necessary to better understand the atmospheric variability of PV power generation. For example, there are large variations between rainy and dry seasons, between days with high and low dust levels - caused by sandstorms (harmattan) or urban air pollution.

In our paper, we investigate different aspects of aerosol characteristics on PV hybrid systems in West Africa. Based on measured data from different sources (AERONET, DACCIWA, EnerSHelF), we will investigate the influence of aerosol density and type on PV performance by comparing a nonspectrally resolved (Neher et al., 2017) and a spectrally resolved PV performance model (HermanCzezuch et al., submitted). Due to the materials used (semiconductors e.g. silicon, gallium arsenide, cadmium telluride), photovoltaic cells are spectrally selective. This means that only radiation of certain wavelengths is converted into electrical energy. A material property called spectral sensitivity characterizes a certain degree of solar radiation conversion into the electric current for each wavelength of sunlight. On the other hand, different types of aerosols can be distinguished by their scattering and absorption properties. A fundamental study of the impact of spectral effects due to different aerosol types is essential to improve PV power predictions under aerosol-dominated situations, such as dust storms or urban smog.

The current study is part of the EnerSHelF (Energy Self-sufficiency of Health Facilities in Ghana) research project funded by the German Federal Ministry of Education and Research (BMBF) and coordinated by the Bonn-Rhein-Sieg University of Applied Sciences (H-BRS)

Here we present model results in which we systematically investigate the impact of aerosols on PV performance for different PV technologies. In addition, we show results of a case study investigating the impact of desert dust on a real PV hybrid system during the harmattan season (Bebber et al., 2021).

\section{References}

- Bebber, M., et al., „PV-Diesel-Hybrid-System für ein Krankenhaus in Ghana - Anbindung eines PVBatteriespeichermodells an ein bestehendes Generatormodell." Hochschule Bonn-Rhein-Sieg, 2021 (IZNE Working Paper Series, Nr. 21/3.) (Research Paper.) ISBN 978-3-96043-091-9 
- Herman-Czezuch, A., et al., "Impact of solar spectrum on the efficiency of photovol-taic cells spectrally resolved PV performance model", submitted to Solar Energy, 2021

- Neher, I, et al., "Impact of aerosols on photovoltaic energy production - Scenarios from the Sahel Zone". In: Energy Procedia, Vol.125, 2017, S. 170-179 